\title{
The Juxtaposition of Antithetical Forces in the Fault in Our Stars by John Green
}

\author{
* Sarwat Javed, Assistant Profess or (Corresponding Author) \\ ** Qamar Hussain, Lecturer \\ *** Asima Abdul-Rehman, BS English
}

\begin{abstract}

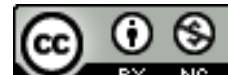

This research paper seeks to study the juxtaposition of antithetical forces in the text The Fault in Our Stars penned down by John Green. The research centers on the characters' quest for finding an answer to the meaninglessness, attempts for filling the void, facticity, existential ang st, and ultimate despair in the framework of the philosophy of 'Existentialism' posited by Jean-Paul Sartre. All the major characters in the novel are cancer patients, living a dismal and distressing life under the looming shadow of death. In an existential vein, the protagonists set out on a journey of selfexploration and choose to eke out a momentary optimism from their pessimistic situations. While battling with the terminal disease, Hazel Grace Lancaster and Augustus Waters engage in an emotional liaison that becomes a redeeming force in their traumatized existence. This research will study how love becomes a life force, an antithetical force juxtaposed with death and devastation. The transience becomes an impetus of change from despair to fulfillment as the protagonists experience infinity in an ephemeral togetherness and find a meaning of life in empathy and love.
\end{abstract}

Keywords: Antithetical Forces, Death, Existential Angst, Despair, Love, Life, Fulfilment Introduction

Stop and consider! life is but a day;

A fragile dew-drop on its perilous way

From a tree's summit; a poor Indian's sleep

While his boat hastens to the monstrous

steep Of Montmorenci.(Keats,1816,L.85-

89)

Temporality lends enchantment to life and the value of life is only visible in the eyes of death. Death evokes a sense of decay and degeneration as a natural corollary. In The Fault in our Stars, John Green portrays the characters battling cancer. Death hovers in the novel from beginning to the end but the writer has portrayed the other side of the dark picture by making the protagonists passionate about here and now. Images of disease, death, and decay permeate the narrative of the novel and reinforce the idea of transitivity of life. Aside from creating tragic effects, ephemerality paradoxically reflects the significance of life in an optimistic way.

Hazel and Augustus are kids devastated by their terrible destiny and mulling over existential questions. The purpose of life is an existential question for anyone, but this question is more enigmatic to the characters in the novel who confront an abhorring lack of purpose and meaning in life. The three main characters in the novel struggle with cancer. Isaac suffers due to eye cancer. Hazel is diagnosed with lung cancer deteriorating day by day and Augustus is struggling with relapsing cancer. They meet in the 'Cancer Support Group', a group of all the ailing people who meet intermittently, share their problems and the remedies to lessen their agony. Despairing their sufferings and the purpose of their existence, they undergo existential angst and feel stranded in this universe of time and space.

Existentialism is a school of thought pioneered by Soren Kierkegaard and later accentuated by Jean-Paul Sartre. Existentialism enunciates an individual's existence as an independent agent, determining his own choices and responsible for living through the consequences of those choices. This research studies The Fault in Our Stars in the light of existential philosophy that how far the characters are free to make choices, how they cope up with the absurdity and struggle to carve out a

\footnotetext{
* Govt. Post Graduate College (W), Satellite Town Gujranwala, Punjab, Pakistan

** University of Sargodha, Punjab, Pakistan

*** Govt. Post Graduate College (W), Satellite Town, Gujranwala, Punjab, Pakistan
} 
meaning out of the apparent meaninglessness of their existence. This paper contends that death is an impetus, an antithetical force juxtaposed with life that prods the protagonists' aspiration to make life meaningful and worthwhile. Despite the torments of the deadly disease and prospective short period in this phenomenological world, they try to find optimism in pessimism through love.

\section{Literature Review}

To contextualize the area of research in this paper, it is imperative to chronicle all the previous articles, reviews, and dissertations available on this acclaimed novel.

A research article entitled 'Living with Cancer: The Fault in our Stars' by Susan Gubar written on 12 June 2014 appreciates the art of characterization as the writer portrays the malaise of teen-ager cancer victims but in turn, they reflect the trouble and sufferings of all the people fighting cancer, both young and old. The novel has a universal appeal, an all-inclusive fiction that mirrors the agony of all the sick people.

Rachel Syme in the article 'The Fault in Our Stars': Love in a Time of Cancer endorses this novel as brilliant and bitter-sweet. The reviewer writes that this novel is superb in plot construction in which happiness and joy are contrapuntal like the musical notes. In the beginning, the protagonists are pessimistic and seem to have given up on life but they develop a zest for life after they meet in 'Cancer Support Group'. Despite their perpetual suffering and physical degeneration, love and companionship regenerate their souls.

Moreover, in an essay titled The Fault in our Stars at Book Analysis, UK Essays, an anonymous writer appreciates the novel as a perfect literary work and ascribes its appeal to plausibility and verisimilitude. This essay acknowledges and appreciates John Green's technical excellence in writing a well-made plot and depicting life-like characters.

A thesis titled Psychological Relationship in The Fault in Our Stars Novel: An Analysis of Social Exchange by Nurhuda Fithroni at State Islamic University, Jakarta in 2017 is the most accomplished research work on this novel. In this thesis, Nurhuda Fithroni conducts analytical research on the relationship between Hazel and Augustus as the major characters. An excerpt from the abstract of her thesis is quoted here for authentication of this literature review. The scholar, Nurhuda, writes in an abstract that she analyzes the relationship between the major characters in the light of the psychological dimension in the social exchange theory. Her research features an in-depth study of the potent factors for friendship as enunciated by Robert S. Feldman's theory. Moreover, her study includes the relationship analysis by applying J.W Thibaut and H.H Kelley's social exchange theory. Regarding the analytic part of the research, the writer elucidates that the relationship needs perpetuity factors to thrive such as compatibility, reciprocal love, positive qualities, beauty, and outlook. In conclusion, Fithroni commends that the emotional bonding between Hazel and Augustus is strong, cordial, and reciprocal.

After a brief survey of various aspects explored in the novel, the present research discusses how death enhances the value of life and what is the response of the characters to terminal diseases awaiting death. In this research, the protagonists' struggle to cope up with their hopeless situations and to find meaning in life will be studied in the framework of existentialism.

\section{Research Methodology}

This research is qualitative in nature and interpretative in design. To explore 'The Juxtaposition of Antithetical Forces' in The Fault in our Stars, the researchers have used the qualitative approach in the framework of existentialism put forward by Soren Kierkegaard and Jean-Paul Sartre. Different books and journals written on the related topics have been read thoroughly. Besides reading the print medium, some of the data is collected from reliable internet sources. Sufficient information has been gathered from both print and web sources.

Analysis: An Existential Perspective in the Fault in Our Stars

In The Fault in Our Stars, John Green focuses on his characters' consciousness and the absurdity, anguish, and despair in their lives framing the main lenses from which an existentialist sees life. Existentialism postulates that the meaning of life of human beings is what composes their 'true essence', an individual is a conscious being and has the freedom to play his/her role according to personal choice. In his lecture 'Existentialism is Humanism' delivered in 1946, Sartre asserts: "Man first of all exists, encounters himself, surges up in the world-and defines himself afterward" (Sartre,1946, para 5). 
The Fault in Our Stars echoes the same existential idea, the teenage characters Hazel, Augustus, and Isaac find themselves battered in this existence, left to endure pain and suffering in battling with cancer. In the 'Cancer Support Group', Hazel creates an empathetic bond with Augustus Waters in an exchange of apprehensive thoughts about life and death. Their lives hinge on baffling questions about existence. Augustus always sulks over the futility of their existence. Whether he will leave a mark upon the world? How important is it to bequeath a legacy upon posterity? While Hazel always freaks out that how'll her death hurt her parents? Does imagining the 'Heart of Jesus' eliminate the absurdity of existence? The character development in the novel occurs through these enigmatic questions.

In the meetings of 'Cancer Support Group', sitting in the rings and imagining to be in the 'Heart of Jesus' resonates Soren Kierkegaard's idea of 'Leap of Faith' in the larger perspective of absurdism. 'Leap of Faith' is a belief to endure absurdity and seek redemption through imaginatively aligning to a divine agency transcending the physical realm. Through a 'Leap of Faith', people seek comfort in the idea that if they suffer here, they will be rewarded in the world hereafter. Christianity believes in a transcendental realm in which the believers enjoy the presence of God and other believers, living in absolute freedom from suffering and sin. The meeting of 'Cancer Support Group' in the metaphoric 'Heart of Jesus' is an illustration of the same idea. The group meets in a room under the auspices of the cross, where the two boards of the cross intersect. Patrick, the leader of the group, explains that the members of the group flock together in the heart of Jesus and prompts the cancer kids to imagine that young, disease-afflicted people figure prominently in the heart of Jesus. However, Hazel Grace does not confide in this idea. She narrates with an undertone of disdain that all the characters try to live by their support group mantra, 'LIVING OUR BEST LIFE TODAY' (Green, 2012, p.14). Although the cancer kids emulate the support group's vision and try to live the best life every day, yet Hazel often finds religion at odds with her subjective feelings. She ridicules the absurdity in finding solace through a 'Leap of Faith' because, in reality, it does not relieve the pain of members of the 'Cancer Support Group'. John Green has presented religion in a dubious vein. Hazel is skeptical about believes such as 'Leap of Faith. She is near agnosticism, deeply dismayed over the absurdity of life and her facticity.

Facticity, another concept in existentialism, has thrown her into an afflicting and meaningless life. The concept of facticity is explained by Jean-Paul Sartre in 'Being and Nothingness' (1956). Facticity is something that an individual cannot alter, a predetermined biological or socio-economic fact that a person has to live with. Facticity is paradoxically the limitation and freedom at the same time. It is up to an individual to decide whether he wants to remain trapped by the pre-determined facts of his life or accepting the facticity he wants to move forward and make better choices for a meaningful life. Different people respond in different ways while confronting their facticity. Hazel's reaction towards her disease is comparatively more intense and pessimistic than that of Augustus that explains multiple reactions of people living through the same conditions and the same facticity. Hazel always tries to remain aloof from the people around her and aggressively tells her parents: “... I'm like a grenade. Mom. I'm a grenade and at some time I'm going to blow up and I would like to minimize the casualties, okay?" (Green, 2012, p.99).

Initially, Hazel feels trapped by her facticity, remains passive and seething because she thinks life has betrayed her. Thinking of herself as a walking grenade that will hurt everyone around her at the end, she tells the reason why she avoids getting closer to new people as she is likely to die soon and leave everyone around her hurt. Hazel's search to know about the ultimate destiny of an ailing character, Anna, in An Imperial Affliction reflects her quest for how to cope up with this appalling reality of death and how will her parents survive the bereavement. Nevertheless, after meeting Augustus, her pessimism dissipates and a newly awakened desire to love and live ensues. She learns to value the importance of life in her happy moments. Her companionship with Augustus kindles her withering soul and she starts relishing life in togetherness. Hazel and Augustus realize that woes of tomorrow must not impinge upon the joys of the moment. Through the course of their lives, they have learned that they must accept the inevitability of suffering and never ruin the joy of the present in the fear of a horrifying future. They accept their facticity as cancer patients and learn how to value life amidst the fear of oblivion. Augustus apprises Hazel in a romantic mood that he loves beauty in all its manifestations and he seeks joy in the simple pleasures of life therefore he cannot deny the charms of life in pining away due to the despondent life conditions. Augustus expresses “...You are beautiful I 
enjoy looking at beautiful people, and I decided a while ago not to deny myself the simple pleasures of existence" (Green, 2012, p.16). Augustus struggles to defy his facticity. He tells Hazel about his metaphor of lightening cigarettes as "They don't kill you unless you light them... It's a metaphor, see: You put the killing thing right between your teeth, but you don't give it the power to do its killing" (Green, 2012, p.20). Such courage and vitality motivate him to live up to positive standards and beliefs despite his deadly disease and abysmal fears. This positivity is also manifest where Augustus vicariously performs virtuous actions in saving some children from unknown terrorists in a video game. He is aware of the ephemerality of all the solutions, happiness, and joy but still, he values them as they mean something in the nothingness of life. Augustus says:

All salvation is temporary...I bought them a minute. Maybe that's the minute that buys them an hour, which is the hour that buys them a year. No one's gonna buy them forever, Hazel Grace, but my life bought them a minute. And that's not anything. (Green, 2012, p.59)

Augustus believes that he must do something before he dies but he regrets he cannot do anything prodigious. Like an existentialist, Augustus is striving to find meaning and leave a mark upon the world instead of silently receding into oblivion. He frets over the apprehension of leaving the world without making a mark upon it. His confrontation with imminent death raises fear of oblivion and a quest for self-actualization in him. Unlike his fellow teenagers, Augustus has no cherished ambitions and aspirations, sadly he has few choices to make because of his physical handicap of an amputated leg and a gnawing disease. Abraham H. Maslow (1968), an American humanist psychologist, propounds that once the instinctive needs are satiated, an individual moves on to higher levels in the hierarchy to accomplish the furthest desire of self-actualization. Selfactualization is the essence of existence that gives an impetus for the acquisition of high ideals, to leave a patrimony to be commemorated and eulogized. As enunciated in Maslow's theory, Augustus wants to do something remarkable to perpetuate his name even after his death. He expresses his point of view in the novel "If you don't live a life in service of the greater good. You have gotta at least die a death in service of the greater good, you know? And I fear that I won't get either a life or a death that means anything" (Green, 2012, p. 168). Augustus has an underlying desire for an extraordinary and charismatic life so that he may be remembered in posterity but unfortunately, his disease and possibly a short span of life are deterrents to the fulfillment of the cherished and un-interpreted dreams. His posthumous eulogy for Hazel also unleashes his unfulfilled dreams:

Almost everyone is obsessed with leaving a mark upon the world. Bequeathing a legacy. Outlasting death. We all want to be remembered. I do, too. That's what bothers me most, is being another unremembered causality in the ancient and inglorious war against disease. I want to leave a mark. (Green, 2012, p.311)

Sadly, this desire to do something memorable and leave a mark on the world remains unquenched. Instead, he leaves a scar upon the world, a painful reminder of his miserable life.

Angst, another feature of existentialism, permeates throughout the novel. All the characters in the novel live in never-ending distress, just passing time without lofty ideals and great goals to pursue. They channelize their anxiety by watching movies, reading books, playing video games with vicarious participation, and hanging out to dispel the tediousness of time. They are always trying to find out whether their lives have meaning and purpose? Were they born to suffer the malaise of this disease and die young? Such afflicting thoughts spawn despair and depression. Moreover, An Imperial Affliction, a novel within a novel, replicate these questions and exasperates the existential angst.

Not only the characters but the title of the novel The Fault in Our Stars, borrowed from Julius Caesar by William Shakespeare, also espouses facticity. John Green has selected the title The Fault in Our Stars as a deviation of the Shakespearean idea that human flaws bring about their doom. The Fault in Our Stars is a subversion of Caesar's utterance "The fault, dear Brutus, is not in our stars / But in ourselves that we are underlings" (Shakespeare, 2010, L-140-141). Shakespeare denies the deterministic element of life while John Green's The Fault in Our Stars argues that sometimes it's not our fault, some facts are pre-determined and can't be avoided or changed like the facticity of the characters in this novel. They have to come to terms with reality, cope up with the absurdity and learn to live with anguish. In the novel, the relationship of the protagonists is quite complicated. Life is a dark hallo where Hazel and Augustus are living on borrowed time dependent on aids like a BiPAP machine and an artificial leg respectively, supporting and encouraging each other in their misery. 
They spend more time thinking about the meaning of life. Hazel and Augustus have the idea that their lives are soon to end therefore they come to realize the craving for life which the normal teenteenagers will never know. They have learned to make the most of life in togetherness. Hence, the dark shadow of imminent death has given an impetus to rejoice in the sparse moments of happiness and transitory existence. They realize the beauty of life through love, in unison, they emerge from deep depression to an acceptance of a tragic reality. Without fear of facing death, the protagonists would never have been able to realize the importance of life at such a tender age. While introducing himself in the cancer support group, Augustus expresses his fear of oblivion as "I fear it like the proverbial blind man who's afraid of the dark" (Green, 2012, p. 12). This reflection evokes a nihilistic apprehension about the world hereafter and remorse over the hopelessness of the human condition. Everyone in the support group and especially Hazel is deeply moved by the pathos in Augustus's remark. Hazel attempts to appease Augustus in her reflections about death as an inevitable reality and an annihilator of all human acquisition. Everything will obliterate and be forgotten. Hazel remarks:

There will come a time when all of us are dead. All of us. There will come a time when no human beings are remaining to remember that anyone ever existed or that our species ever did anything ... Maybe that time is coming soon or maybe it's millions of years away but even if we survive the collapse of our sun, we will not survive forever. There was a time before organisms' consciousness and there will be time after. And if the inevitability of human oblivion worries you, I encourage you to ignore it. (Green, 2012, p.13)

Hazel's statement espouses an idea of nothingness, a generalization of cosmic reality that all human endeavor and progress are bound to recede into nothingness. One must not be cast down at transitivity because longe vity will also end. This is how the se grief-stricken people console each other in the haze of their situatedness.

Amidst the life-denying forces of distress and dejection, John Green has juxtaposed the lifeaffirming forces of love and empathy. Augustus respects Hazel's wishes and tries every bit to bring her joy. Despite his amputation and worsening health condition, he accompanies Hazel to Amsterdam and arranges her visit to the writer of An Imperial Affliction. Augustus's presence in her life changes her worldview, she transforms from a 'living Grenade' to an individual striving to eke out happiness and memorable moments from life. In the pre-funeral of Augustus Hazel prays for more days for herself.

Augustus asks Hazel to speak at his pre-funeral and decides that he wants to listen to what she has to say. Hazel reads amidst tears what she has written, a letter for Augustus. She affirms her indebtedness to Augustus "You gave me forever within the numbered days and I cannot tell you how thankful I am for this little infinity" (Green, 2012, p.259). Hazel endearingly owns their companionship as the most valued possession that she would not barter with anything in the universe. Throughout the novel, they are a source of strength for one another, always trying to ward off the enfeebling effects of the disease. Hence, love as a redeeming force changes life for Hazel and Augustus "not in kind but degree/the instant made eternity" (The Last Ride Together, 1855, L.107). Belongingness mitigates their sense of purposelessness although their physical malaise consistently intensifies drawing them closer to death. Not only do they sustain one another in life but also death. Augustus's death answers the most enigmatic question for Hazel that how to survive a loved one's death? Does Hazel always fret that how will her parents survive her death? That is why Hazel is inquisitive about the fate of Anna, a fictitious character in the novel An Imperial Affliction, with whom she identifies and wants to know how did Anna's mother live through Anna's death. After Augustus passes away; Hazel learns that if she can survive Augustus' demise, her mother will survive her death.

Moreover, Augustus renders permanence to their relationship by expressing his love for Hazel in the letter he sends to Peter Van Houten, the author of An Imperial Affliction. Augustus wants Houten to write a lucid eulogy for Hazel at his behest. The final words of the posthumous eulogy are promising and re-affirm her belief in their eternal love and companionship. Hazel receives the eulogy of Augustus and finds that while articulating his passion, Augustus makes it eternal "I am so lucky to love her. You don't get to choose if you get hurt in the world, but you do have so some say in who hurts you. I like my choices. I hope Hazel likes her too" (Green, 2012, p.313).

Their reassuring and nurturing companionship is accentuated through the loneliness of Isaac, a mutual friend in the cancer support group. Hazel and Augustus are always empathetic to Isaac who 
is near blind due to eye cancer. Hazel and Isaac have an affinity since they meet up in the 'Cancer Support Group'. They share a deep understanding beyond words as both "communicate almost exclusively through sighs" (Green, 2012, p.6). Augustus is always supportive and empathetic to Isaac who is the most dejected in this trio of star-crossed people for being spurned by his beloved Monica who promised to stand by him through thick and thin. Isaac is heartbroken and dismayed over Monica's infidelity. Hazel narrates "Tears streamed down his reddened cheeks in a continual flow, his face a taut mask of pain" (Green, 2012, p.56). This emotional set back along with his deadly disease leaves him distraught and miserable, a prototype of angst and despair.

This research elucidates that from an existential perspective, The Fault in Our Stars incorporates all the features such as absurdity, facticity, angst, and despair. Hazel Grace, Augustus Waters, and Isaac experience excruciating pain and psychological distress due to terminal cancer. They despair about the suffering, boredom, and meaninglessness of their lives. Moreover, John Green has very dexterously juxtaposed the antithetical forces of life and death, hope and hopelessness that mitigate the impact of desolation.

\section{Conclusion}

The novel is built upon the perspective of ailing teenagers passing life under the looming shadow of death. All the major postulates of existentialism resonate in the facticity, absurdity, angst, and despair of the characters. Their facticity has wrecked them in an "inglorious war against disease" (Green, 2012, p.311), forsaken and anguished with no choice but to despair. Nevertheless, their chance meeting in the 'Cancer Support Group' changes the tenor of their lives from pessimism to optimism as togetherness makes life charming. Love placates their tormented souls and brings a psychological respite although their physical conditions worsen persistently. Hence, a juxtaposition of antithetical forces of life and death changes the protagonist's perception of life from a pessimistic, dark and dismal abyss to a fulfilling momentary premise. The impending death has made them relish the importance and value of the here and now. They have taken the lead of their lives, endured their medical conditions, and learnt that "Without Pain, How Could We Know Joy"? (Green, 2012, p. 35)

\section{References}

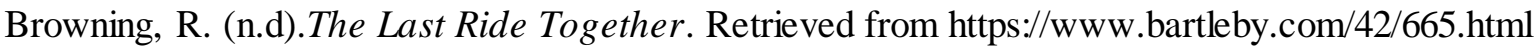
Fithroni, N. (2017).Psychological Relationship in The Fault in Our Stars Novel: An Analysis of Social Exchange. Retrieved from http://repository.uinjkt.ac.id/dspace/bitstream/.pdf

Green, J. (2012). The Fault in Our Stars. Great Britain: Penguin Books.

Gubar, S. "Living with cancer: 'The Fault in Our Stars' New York Times. https://well.blogs. nytimes.com >

Keats, J. (n.d).Sleep and Poetry. Retrieved from https://www.bartleby.com/126/31.html

Kierkegaard, S. (2018, September 26). Kierkegaard's Leap of Faith. Retrieved from https://academic. logos.com/kierkegaards-leap-of-faith.htm

McLeod, S. (2020, December 29).Maslow's Hierarchy of Needs. Retrieved from https://www.simplyp sychology.org/maslow.html

Sartre, J.P. (2005, February). Existentialism is humanism. Retrieved from https://www.marxists.org/ reference/archive/sartre/works/exist/sartre.htm

Shakespeare, W. (2010).Julius Caesar. Oxford: Oxford University Press.

Syme, R. (2012, January 17). 'The Fault in Our Stars': Love in a Time of Cancer. Retrieved from https://www.npr.org > 2012/01/17 > the-fault-in-our-stars/html

UK Essays. (November 2018). 'The Fault in Our Stars' Book Analysis. Retrieved from https://www.ukessays.com/essays/english-literature/the-fault-in-our-stars-bookanalysis.php?vref $=1$ 